\title{
Circulating surfactant protein -D is low and correlates negatively with systemic inflammation in early, untreated rheumatoid arthritis
}

Anne Friesgaard Christensen ${ }^{1 *}$, Grith Lykke Sørensen ${ }^{2}$, Kim Hørslev-Petersen $^{3}$, Uffe Holmskov², Hanne Merete Lindegaard ${ }^{1}$, Kirsten Junker ${ }^{2}$, Merete Lund Hetland ${ }^{4}$, Kristian Stengaard-Pedersen ${ }^{5}$, Søren Jacobsen ${ }^{6}$, Tine Lottenburger ${ }^{3}$, Torkell Ellingsen ${ }^{5}$, Lis Smedegaard Andersen ${ }^{3}$, Ib Hansen ${ }^{5}$, Henrik Skjødt ${ }^{4}$, Jens Kristian Pedersen ${ }^{3}$, Ulrik Birk Lauridsen ${ }^{4}$, Anders Svendsen ${ }^{1}$, Ulrik Tarp ${ }^{5}$, Jan Pødenphant ${ }^{7}$, Aage Vestergaard ${ }^{8}$, Anne Grethe Jurik ${ }^{9}$, Mikkel Østergaard ${ }^{5}$, Peter Junker ${ }^{1}$

\begin{abstract}
Introduction: Surfactant protein D (SP-D) is a collectin with immuno-regulatory functions, which may depend on oligomerization. Anti-microbial and anti-inflammatory properties have been attributed to multimeric SP-D variants, while trimeric subunits per se have been suggested to enhance inflammation. Previously, we reported low circulating SP-D in early rheumatoid arthritis (RA), and the present investigation aims to extend these data by serial SP-D serum measurements, studies on synovial fluid, SP-D size distribution and genotyping in patients with early RA.

Methods: One-hundred-and-sixty disease-modifying antirheumatic drug (DMARD) naïve RA patients with disease duration less than six months were studied prospectively for four years (CIMESTRA (Ciclosporine, Methotrexate, Steroid in RA) trial) including disease activity measures (C-reactive protein, joint counts and Health Assessment Questionnaire (HAQ) score), autoantibodies, x-ray findings and SP-D. SP-D was quantified by enzyme-linked immunosorbent assay (ELISA) and molecular size distribution was assessed by gel filtration chromatography. Further, SP-D Met11Thr single nucleotide polymorphism (SNP) analysis was performed.
\end{abstract}

Results: Serum SP-D was significantly lower in RA patients at baseline compared with healthy controls $(P<0.001)$. SP-D increased slightly during follow-up $(P<0.001)$, but was still subnormal at four years after adjustment for confounders $(P<0.001)$. SP-D in synovial fluid was up to 2.5 -fold lower than in serum. While multimeric variants were detected in serum, SP-D in synovial fluid comprised trimeric subunits only. There were no significant associations between genotype distribution and SP-D. Baseline SP-D was inversely associated to CRP and HAQ score. A similar relationship was observed regarding temporal changes in SP-D and CRP (zero to four years). SP-D was not associated to $x$-ray findings.

Conclusions: This study confirms that circulating SP-D is persistently subnormal in early and untreated RA despite a favourable therapeutic response obtained during four years of follow-up. SP-D correlated negatively to disease activity measures, but was not correlated with $x$-ray progression or SP-D genotype. These observations suggest that SP-D is implicated in RA pathogenesis at the protein level. The exclusive presence of trimeric SP-D in affected joints may contribute to the maintenance of joint inflammation.

Trial registration: (j.nr NCT00209859).

\footnotetext{
* Correspondence: a.friesgaard@gmail.com

'Department of Rheumatology, Odense University Hospital, Sdr. Boulevard

29, DK-5000 Odense C, Denmark and Institute of Clinical Research, University

of Southern Denmark, Winsloewparken 19, DK-5000 Odense C, Denmark
} 


\section{Introduction}

Within recent years, search for innate immune system abnormalities in rheumatoid arthritis (RA) has attracted considerable attention [1]. Thus, low serum levels of mannan-binding lectin (MBL) have been associated with increased risk of early disease onset and severity of RA [2,3]. Likewise, variant MBL alleles have been associated with an unfavourable disease course [4,5]. Recently, we reported that the serum level of another collectin, surfactant protein D (SP-D), is decreased in newly-diagnosed, untreated RA [6]. In that study comprising 45 DMARD naïve patients, systemic SP-D was not significantly associated to conventional measures of disease activity such as C-reactive protein and joint counts [6].

Collectins are pattern recognition molecules, which preferentially bind to carbohydrate moieties expressed on a variety of pathogens (pathogen associated molecular patterns (PAMPs)), thereby enhancing aggregation, opsonisation or MBL-mediated complement activation [7]. SP-D has a complex quaternary structure in which monomers are assembled into tetramers forming dodecamers or higher order multimers [8,9]. Multimeric SP$\mathrm{D}$ is suggested to have anti-microbial properties [10-13]. The function of natural trimeric subunit SP-D is not known in detail, but it seems to be devoid of antiinflammatory activity [10-13]. SP-D is primarily synthesized by the respiratory epithelium (type II epithelial cells and Clara cells) $[14,15]$, but is also expressed in a variety of extra-pulmonary epithelia [16]. SP-D has been detected in various body fluids including serum, synovial fluid, lacrimal and broncho-alveolar lavage liquid [17-22]. A common polymorphism in the SP-D gene on chromosome 10, Met11Thr, resulting in either methionine or threonine at residue 11, is a major determinant for the serum concentration and multimerization of SPD $[13,22]$. The Thr11-variant is associated with reduced oligomerization, reduced binding capacity of microbes and low serum levels in healthy subjects [13].

The present investigation extends our previous observation by readdressing the possible association between SP-D and the Met11Thr polymorphism in early, untreated RA, and by studying the correlation between SP-D and disease activity measures and radiographic progression during a four-year interventional study on DMARD naïve patients with RA of recent onset. In addition, we compared the SP-D molecular size distribution in synovial fluid and corresponding sera.

\section{Materials and methods \\ Patients and controls}

One-hundred-and-sixty RA patients were included in the multicenter, randomized, double-blinded, parallelgroup, placebo-controlled CIMESTRA trial $[23,24]$.
Briefly, patients fulfilled the American College of Rheumatology 1987 revised criteria for RA [25]. Further, the patients appeared with active disease less than six months, less than or equal to two swollen joints at baseline, and were aged 18 to 75 years $[23,24]$. Health Assessment Questionnaire (HAQ score, 0 to 3) [26], Visual Analogue Scale (0 to 10) (VAS pain, global and doctor) and Disease Activity Score in 28 joints (DAS28) [27] were calculated. Fourteen-hundred-and-seventy-six healthy twin-individuals aged 18 to 67 years served as controls [22]. The trial was approved by the local ethics committee (j. nr M1959-98) and fulfilled the Declaration of Helsinki and the International Conference on Harmonisation 1996 revised guidelines for Good Clinical Practice (j.nr NCT00209859). Signed informed consent was obtained from all study participants.

\section{Treatment strategy}

The treatment protocol compared methotrexate (MTX) plus cyclosporine vs. MTX plus placebo. During the first eight weeks patients were assessed fortnightly and every four weeks thereafter. Subsequently, whenever synovitis was present MTX dose was escalated by $2.5 \mathrm{mg}$ from $7.5 \mathrm{mg} /$ week to maximum $20 \mathrm{mg} /$ week followed by a stepwise cyclosporine/placebo-cyclosporine increment $(0.5 \mathrm{mg} / \mathrm{kg})$ every four weeks from $2.5 \mathrm{mg} / \mathrm{kg}$ to maximum $4.0 \mathrm{mg} / \mathrm{kg}$. In addition, intra-articular betamethasone $(7 \mathrm{mg} / \mathrm{l})$ was injected into swollen joints at any visit (maximum four joints or $4 \mathrm{ml}$ per visit). During the second year, hydroxychloroquine (200 $\mathrm{mg} /$ day) was added and cyclosporine/placebo was tapered to zero, while MTX was continued [23,24]. During the open extension study from three to four years the treatment strategy continued to aim at tight synovitis control. Oral glucocorticoids were allowed in the open extension study.

\section{Laboratory measures}

Serum was obtained from routinely drawn non-fasting blood samples collected between 08.00 a.m. to 2.00 p.m. Samples were allowed to clot at room temperature followed by centrifugation at $3,000 \times \mathrm{g}$ for 10 minutes. Sera were stored at $-80^{\circ} \mathrm{C}$.

SP-D was measured at baseline, after two weeks, one and six months, and after one, two, three and four years using a five-layered sandwich ELISA as previously described [19]. In controls, SP-D was only measured at baseline. All analyses were done in duplicate and serial samples from the same patient were analyzed simultaneously. The inter-assay coefficients of variation were 3.5 and $3.8 \%$ for low $(367 \mathrm{ng} / \mathrm{ml})$ and high $(2,470 \mathrm{ng} /$ $\mathrm{ml}$ ) quality controls, respectively, and the intra-assay coefficients of variation were $1.7 \%$ for both quality controls. C-reactive protein (CRP) (mg/l) and erythrocyte 
sedimentation rate (ESR) ( $\mathrm{mm} /$ hour) were assayed by standard methods. IgM-rheumatoid factor (IgM-RF) (cut-off level $<16 \mathrm{IU} / \mathrm{ml}$ ) and anti-CCP (cut-off level < $24 \mathrm{U} / \mathrm{ml}$ ) (Euro Diagnostica AB, Malmö, Sweden) were measured by ELISA as previously described [28-30].

\section{Radiographic analysis}

Radiographs of hands, wrists, and forefeet were obtained at baseline $(\mathrm{n}=155)$, and annually thereafter. After four years 137 radiographs were available, but only 133 patients had radiographs available at baseline and at four years. Radiographs were scored according to Sharpvan der Heijde by an independent senior radiologist who was aware of the sequence of $\mathrm{x}$-ray recordings [31]. The annual estimated progression rate in total Sharpvan der Heijde Score (TSS), Joint Space Narrowing score (JSN) and erosion score (ES) was calculated according to disease duration and TSS, JSN and ES at baseline for each patient [32]. Radiographic progression was defined as the smallest detectable difference from baseline (= one unit).

\section{Synovial fluid}

Corresponding serum and synovial fluid samples were available from 20 RA patients with joint effusions before treatment. Synovial fluid was collected by aseptic technique before injection of glucocorticoid and stored at $-80^{\circ} \mathrm{C}$. Before analysis, the samples were centrifuged 30 minutes at $400 \times \mathrm{g}$ and subsequently the supernatant was incubated four hour at $37^{\circ} \mathrm{C}$ with bovine testicular hyaluronidase (Sigma H3884, St Louis, MO, USA) to reduce viscosity $(2 \mu \mathrm{l}$ hyaluronidase $(1 \mathrm{mg} / \mathrm{ml}$ in $0.2 \mathrm{M}$ TRIS, $0.1 \mathrm{M}$ sodium acetate, $\mathrm{pH} 7.0$ ) to $300 \mu \mathrm{l}$ synovial fluid). Subsequently, they were centrifuged at $20.000 \times \mathrm{g}$ for 10 minutes at $4^{\circ} \mathrm{C}$. The supernatant was assayed for SP-D by ELISA. The possible trapping of SP-D in the synovial fluid pellet was studied by incubating the pellet with ethylenediaminetetraacetic acid (EDTA) $0.52 \mathrm{M}$ in a TRIS-buffered saline (TBS) buffer ( $\mathrm{pH} \mathrm{7.4)}$ ) at $37^{\circ} \mathrm{C}$ in 30 minutes followed by centrifugation in four minutes at $20.000 \times \mathrm{g}$ and $4^{\circ} \mathrm{C}$. A total of $50 \mu \mathrm{l}$ of the resulting supernatant was re-calcified with $60 \mu \mathrm{l}$ of $1 \mathrm{M} \mathrm{CaCl}_{2}$, and $\mathrm{pH}$ was adjusted to 7.9 by adding $28.5 \mu \mathrm{l} 1 \mathrm{M}$ TRIS $\mathrm{pH} 8.6$ prior to analysis.

\section{Gel filtration chromatography}

Gel filtration chromatography was done on available synovial fluid samples $(\mathrm{n}=11)$ and corresponding sera. Hyaluronidase-treated samples $(200 \mu \mathrm{l})$ were applied to an analytical Superose 6 column connected to a fastperformance liquid chromatography system (former Amersham Biosciences, now GE Healthcare, Uppsale, Sweden) using TBS (pH 7.4) containing $10 \mathrm{mM}$ EDTA and $0.05 \%$ emulphogen as eluent at a flow rate of $24 \mathrm{ml} / \mathrm{hr}$. Fractions of $0.2 \mathrm{ml}$ were collected and quantified by the SP-D ELISA. SP-D was eluted as two structurally different forms with high and low molecular weight (SP-D multimers (fraction 10 to 18) and SP-D trimers (fraction 24 to 38 )). Size chromatography on healthy serum followed by SDS-PAGE and Western blotting has yielded protein bands at $>250 \mathrm{kDa}$ for multimeric SP-D, and $90 \mathrm{kDa}, 43 \mathrm{kDa}$ and $40 \mathrm{kDa}$ for trimeric SP-D [13,19].

\section{Genotyping}

Genomic DNA was isolated from EDTA stabilized whole blood. Applied Biosystems (Assay-by-design) (Foster City, California, USA) designed primers and probes for the non-synonymous substitutions of DNAbases of the SP-D gene resulting in the Met/Thr variant. The genotyping procedure has been described previously [13]. Human leucocyte antigen (HLA)-DRB1 genotyping for shared epitope (SE) was performed by polymerase chain reaction-based sequence-specific oligonucleotide probing, as described elsewhere [33,34]. Herein, we define the shared epitope as the presence of HLADRB1*04 and/or HLADRB1*01 and/or HLADRB1*10.

\section{Statistical analysis}

All statistical analyses were conducted using STATA version 9.2 (StataCorp, College Station, Texas, USA). Comparisons between groups were done by MannWhitney U-test or Fischer's Exact Test, and if analysing more than two groups, Kruskal-Wallis test was used. Spearman Rank Correlation analysis was applied when appropriate. Comparison between patients and controls was performed using linear regression models, where control twins were clustered in pairs. Linear regression was also applied in the prospective analysis of SP-D in RA patients, where repeated measurements in the individual patient were clustered. We used logistic regression to assess whether baseline SP-D could predict radiographic progression after four years with adjustment for gender, age, smoking, anti-CCP and radiographic status at baseline. Robust estimation of standard error was calculated. To approximate a normal distribution, SP-D was logarithmically transformed when used as continuous, dependent variable in linear regression analyses.

One individual from each healthy twin pair was used for genotype and allele frequency estimation. The genotype frequencies were tested for Hardy-Weinberg equilibrium by $\left(\chi^{2}\right.$-analysis. Comparisons of genotype and allele frequencies in patients and controls were performed by logistic regression with adjustment for gender and age or by Fishers Exact test.

Since SP-D did not differ between treatment arms, data from all RA patients were pooled. Analysis was by intention-to treat $(\mathrm{N}=142)$. Completers' analysis was 
also performed and gave similar results (data not shown). Results are presented as median (95\% confidence interval) if not otherwise stated. $P$-values $\leq 0.05$ and $P \leq 0.01$ were considered significant with single and multiple testings, respectively.

\section{Results}

\section{RA patients and controls}

Of 160 patients included, 61 (38\%) did not complete the four-year protocol. The reasons for drop-out were adverse events (11), treatment failure (10), patients' request (13) and other (27). Fifty-six (35\%) left the study during the first two years. Patients who dropped out did not differ from completers with regard to demographic and clinical variables at baseline (data not shown). At baseline one patient had serum SP-D of $8,106 \mathrm{ng} / \mathrm{ml}$. This patient subsequently developed severe pulmonary fibrosis and was excluded from the statistical analyses.

The demographic characteristics of the RA patients at baseline and the control population are shown in Table 1 . Among the 142 patients included in the intention-to-treat analyses, all data for composite disease activity measures were available in 134 individuals. Seventy-eight percent, $66 \%$ and $69 \%$ had achieved ACR50, ACR70 and DAS28 < 2.6 after four years.

Including patients with radiographs available at both baseline and after four years $(\mathrm{N}=133), 53 \%, 23 \%$ and $49 \%$ progressed radiographically according to TSS, JSN and ES score, respectively. Of note, however, radiographic progression at four-year follow-up was small in terms of Sharp/van der Heijde units (median (iqr): TSS 2 (0 to 7$)$ to 5 (0 to 11 ), JSN 0 (0 to 2 ) to 0 (0 to 4$)$ and ES 2 ( 0 to 5$)$ to 3 (0 to 8$)$ ).

\section{Serum SP-D in RA}

Baseline SP-D in RA patients was $693 \mathrm{ng} / \mathrm{ml}(649 ; 770)$ vs. $913 \mathrm{ng} / \mathrm{ml}(879 ; 945)$ in controls $(P<0.001)$. This difference persisted after adjustment for age, gender and current smoking status $(P<0.001)$ and was also present at four years after adjustment for confounders $(P<$
0.001). Compared to baseline, SP-D had increased in RA patients at four years $(893 \mathrm{ng} / \mathrm{ml}[810 ; 1013]$ vs. $693 \mathrm{ng} /$ $\mathrm{ml}[649 ; 770], P<0.001)$ even when adjusting for gender, age and smoking status $(\mathrm{p}<0.001)$. However, at four years, SP-D was still lower in RA patients as compared to controls with adjustment for confounders $(P<$ $0.001)$. There was no significant correlation between age and SP-D in the RA population ( rho $=0.06, P=0.42$ ). Likewise, there was no significant gender difference among RA patients. In contrast, SP-D increased significantly with age in healthy subjects (rho $=0.21, P<$ 0.001 ), and control males had significantly higher levels of SP-D compared to females (Table 2). Both RA and control smokers had significantly higher SP-D than non-smokers (Table 2). Disease activity markers and HAQ score were inversely correlated to SP-D at baseline (CRP: rho $=-0.30, P<0.001$, DAS28: rho $=-0.23, P=$ 0.003 and HAQ: rho $=-0.21, P=0.008)$. No significant difference in SP-D at baseline was observed between patients with respect to anti-CCP, IgM-RF status or any SE present $(P=0.50, P=0.14$, and $P=0.24$, respectively). Furthermore, SP-D did not differ between smoking SE positive vs. non-smoking SE positive patients $(P$ $=0.13$ ).

Table 2 Baseline surfactant protein $D$ in serum $(\mathrm{ng} / \mathrm{ml})$ in smokers and non-smokers and according to gender in patients and controls

\begin{tabular}{lll}
\hline & RA-patients & Controls \\
\hline Men & $760(665 ; 1059)$ & $967(921 ; 1024)$ \\
Women & $674(613 ; 759)$ & $852(818 ; 902)$ \\
P-value* & 0.09 & $<0.001$ \\
Smokers & $850(686 ; 1014)$ & $1187(1099 ; 1293)(\mathrm{n}=482)$ \\
& $(\mathrm{n}=57)$ & \\
Non-smokers & $\begin{array}{l}671(604 ; 738) \\
(\mathrm{n}=101)\end{array}$ & \\
& 0.03 & $<0.001$ \\
\hline -value* & &
\end{tabular}

Median [95\% Cl], * Mann-Whitney U-test

$\mathrm{RA}$, rheumatoid arthritis

Table 1 Demographic characteristics of RA patients at baseline and healthy controls

\begin{tabular}{llll}
\hline Characteristics & RA patients $(\mathbf{N}=\mathbf{1 6 0})$ & Controls $(\mathbf{N}=\mathbf{1 4 7 6})$ & $\boldsymbol{P}$-value \\
\hline Gender f/m (\%women) & $107 / 53(67 \%)$ & $761 / 715(52 \%)$ & $P<0.001$ \\
Age in years & $53(42$ to 63) & $38(29$ to 46$)$ & $P<0.001$ \\
Current smokers (\%) & $57(36 \%)$ & $482(33 \%)$ & $P=0.42$ \\
Disease duration (months) & $3.5(2.7$ to 5.0$)$ & - & - \\
IgM-rheumatoid factor positive (\%) & $103(65 \%)$ & - & - \\
Anti-CCP positive (\%) & $93(58 \%)$ & - & - \\
Any SE present (\%) & $116(73 \%)$ & - & - \\
\hline
\end{tabular}

Median (inter-quartile range)

Comparison between groups was carried out using Mann-Whitney U-test and Fischers Exact test

Anti-CCP, antibodies against cyclic citrullinated peptides; SE, shared epitopes; RA, rheumatoid arthritis 
The CRP change from baseline to four years $(\Delta)$ correlated inversely to the SP-D change $(\triangle \mathrm{CRP}$ vs. $\triangle \mathrm{SP}-\mathrm{D}$, rho $=-0.39$ and $P<0.001)$. We found no association between SP-D and radiographic data including estimated annual progression rate (data not shown). Baseline SP-D did not predict radiographic progression (Total Sharp score) at four years $(P=0.46)$

\section{SP-D in synovial fluid and corresponding sera}

Synovial fluid was obtained from 20 patients at baseline. Median SP-D in synovial fluid was $275 \mathrm{ng} / \mathrm{ml}(221 ; 299)$. SP-D in corresponding sera was $678 \mathrm{ng} / \mathrm{ml}(592 ; 829)$. SP$D$ in synovial fluid and serum levels correlated significantly (rho $=0.69, P<0.001$ ), Figure 1. Synovial fluid SP-D was not significantly associated with sex, age, CRP, autoantibodies, any SE or radiographic findings (data not shown). There was no detectable SP-D in the debris enriched pellets resulting from centrifugation of the synovial fluid. Results from the gel filtration chromatography are outlined in Figure 2. Multimeric SP-D was barely detectable in synovial fluid as compared to serum, where both multimeric and trimeric molecular variant SP-D (trimeric subunits) were detected.

\section{Genetic SP-D variation in RA}

The Met11Thr polymorphism was in Hardy-Weinberg equilibrium in both RA and controls (data not shown). The distribution of genotypes and allele frequencies is presented in Table 4. When adjusting for gender and age, there was no overrepresentation of Thr11Thr in RA patients as compared with controls (Table 3). Circulating SP-D did not differ between genotypes in RA patients, whereas healthy individuals with the Thr11Thr genotype appeared with the lowest level as previously reported [22]. The genotypes were not associated with specific disease features including DAS28, CRP, joint counts, auto-antibodies, HAQ or x-ray findings (data not shown). The Met11Thr allelic variation could neither predict $\mathrm{x}$-ray progression nor disease activity outcome after four years and the size distribution of SP$\mathrm{D}$ in synovial fluid did not differ between genotypes (data not shown).

\section{Discussion}

Based on the structural similarity between SP-D and MBL and our preliminary report on low circulating SPD in RA [6], this investigation was conducted to study the possible role of SP-D as disease modifier in RA. While confirming that SP-D in serum is significantly decreased in newly-diagnosed, untreated RA sufferers, we also found an inverse correlation between SP-D and measures of disease activity at baseline. Although SP-D increased significantly during follow-up, it remained subnormal at four years.

The cause of low SP-D in RA is uncertain and different mechanisms may be involved. Altered SP-D

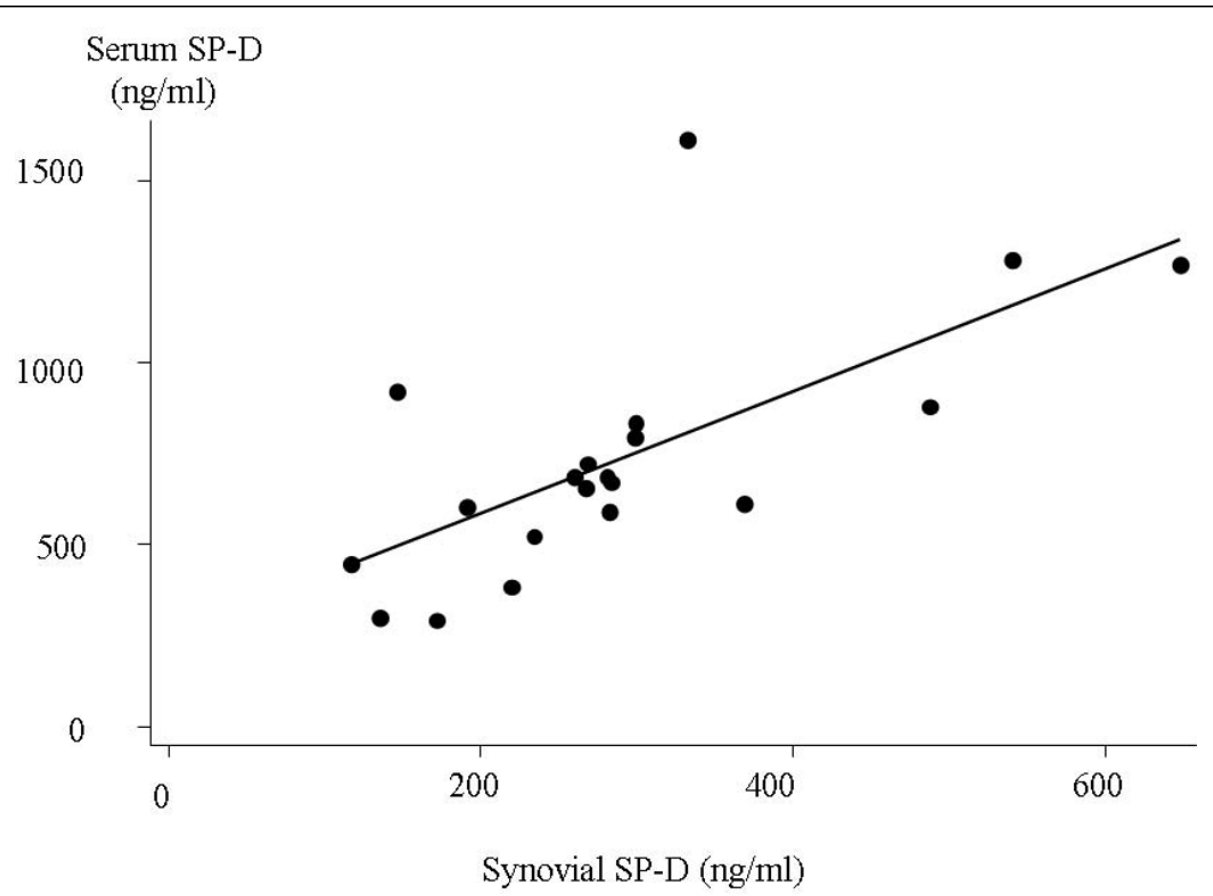

Figure 1 Scatter plot of SP-D in serum and synovial fluid at baseline $(\mathbf{n}=\mathbf{2 0})$. Fitted values are depicted by the line. SP-D, surfactant protein D. 


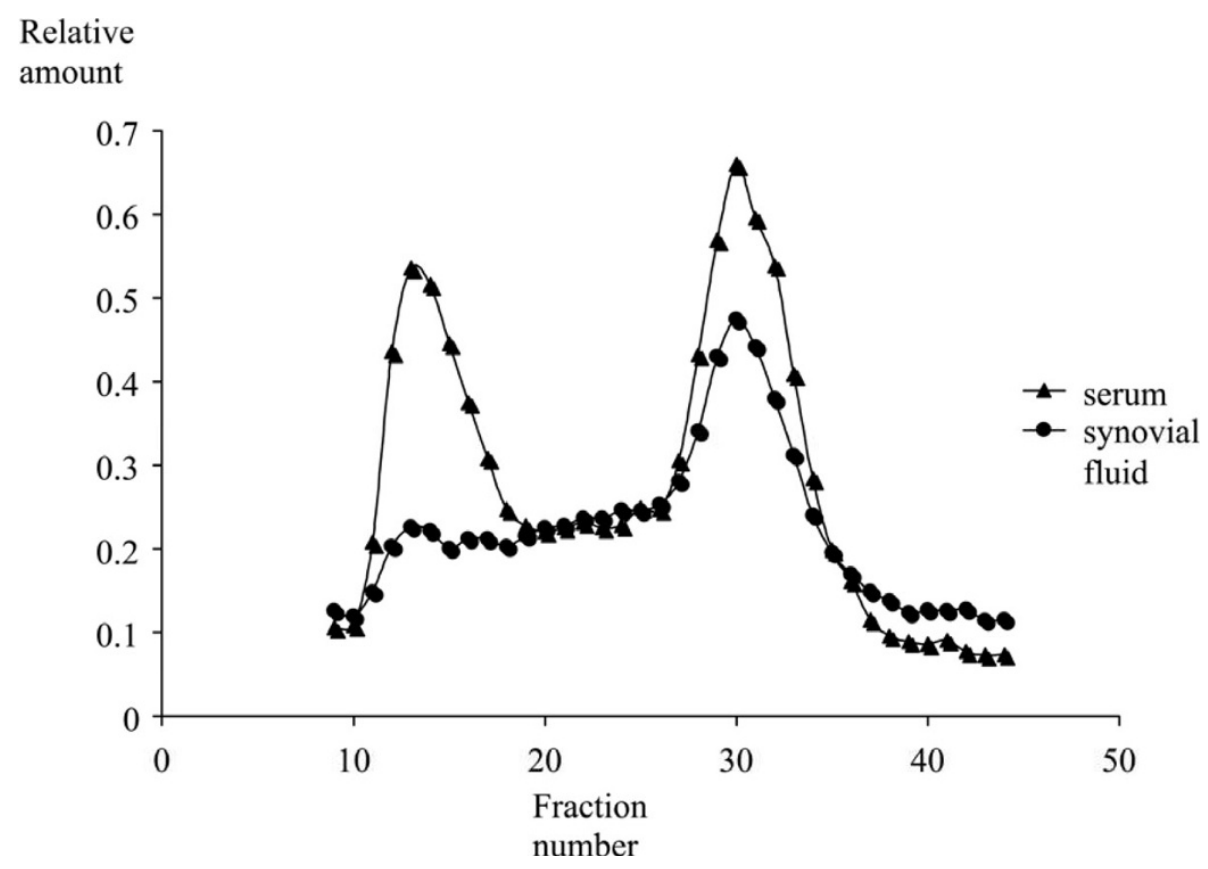

Figure 2 Size exclusion chromatography of SP-D in serum and synovial fluid. Mean curves of 11 corresponding serum and synovial fluid samples. SP-D was eluted as two structurally different forms (SP-D multimers (fraction 10 to 18) and SP-D trimers (fraction 24 to 38)). SP-D, surfactant protein D.

Table 3 Distribution of the SP-D Met11Thr genotype and allele frequencies and corresponding SP-D serum levels (median $(95 \% \mathrm{CI}))$

\begin{tabular}{|c|c|c|c|c|c|c|}
\hline & $\mathrm{N}(\%)$ of RA patients & $\begin{array}{l}\text { SP-D } \mathrm{ng} / \mathrm{ml}^{*} \\
\mathrm{RA} \text { patients }\end{array}$ & $N(\%)$ of controls & $\begin{array}{l}\text { SP-D ng/ml* } \\
\text { Controls }\end{array}$ & $P$-value ${ }^{* *}$ & Odds ratio ${ }^{* * *}$ \\
\hline \multicolumn{7}{|l|}{ Genotype: } \\
\hline Met11/Met11 & $41(27.3)$ & $724(636 ; 1,123)$ & $152(35.8)$ & $1,081(996 ; 1,252)$ & $P=0.16$ & 1.0 (ref) \\
\hline Thr11/Thr11 & $27(18.0)$ & $750(603 ; 834)$ & $77(18.1)$ & $896(788 ; 955)$ & & $1.3(0.73 ; 2.4)$ \\
\hline Met11/Thr11 & $82(54.7)$ & $660(563 ; 761)$ & $196(46.1)$ & $925(845 ; 1,023)$ & & $1.6(0.97 ; 2.6)$ \\
\hline \multicolumn{7}{|l|}{ Allele: } \\
\hline Met11 & $164(54.7)$ & & $500(58.8)$ & & $P=0.22$ & 1.0 (ref) \\
\hline Thr11 & $136(45.3)$ & & $350(41.2)$ & & & $1.2(0.9 ; 1.6)$ \\
\hline
\end{tabular}

* Kruskal-Wallis test: RA patients: $P=0.13$ and controls: $P=0.0023$

** Distribution, $P$-value calculated using Fishers' Exact test

*** Odds ratio $(95 \% \mathrm{Cl})$ calculated using logistic regression with health status as the dependent variable and genotype/allele, gender and age as independent variables.

$\mathrm{Cl}$, confidence interval; SP-D, surfactant protein -D; RA, rheumatoid arthritis; Ref, reference

expression due to genotype abnormalities should be considered. Thus, in healthy subjects the Thr11-variant is associated with low SP-D in the circulation [22].

In the previous study by Hoegh et al [6], the Thr11 variant tended to be overrepresented in RA patients as compared to controls. This trend was not confirmed in the present study. Thus, a clear genetic contribution to low SP-D in RA cannot be identified in this study. However, a possible genetic contribution to low SP-D in RA cannot be completely disregarded from this study due to the limited sample size. Moreover, it should be borne in mind, that focusing at only one polymorphism in the analysis of gene patterns and serum SP-D, may underestimate the significance of a genetic association, which is better represented by haplotype blocks [35].

Decreased SP-D in RA could be attributable to increased clearance from the circulation, for example, by deposition in inflamed tissues or complex formation with, for example, microbial or cellular waste [36,37]. Thus, cells undergoing apoptosis express auto-antigens, which may lead to auto-antibody formation [38]. Both in vitro and in vivo experiments have indicated that 
SP-D enhances clearance of DNA and apoptotic cells by macrophages, thereby reducing anti-dsDNA antibody generation $[36,39,40]$. Such a scavenger mechanism for SP-D in RA is supported by the inverse association between SP-D and disease activity measures and by the gradual SP-D increase during treatment. The inverse association of SP-D and inflammatory signs and the lack of association between SP-D and erosive progression after four years indicate, that subnormal SP-D is primarily linked to systemic inflammation. According to this, depressed systemic SP-D may contribute to persistent low-grade, subclinical joint inflammation as evidenced by MRI and ultrasonic findings [41,42].

In order to further elucidate the possible role of SP-D in joint inflammation, we quantified SP-D in paired serum and synovial samples and studied the molecular size distribution in serum and synovial fluid. We found a SP-D serum:synovial fluid ratio at approximately $3: 1$, which indicates that SP-D reaches the joint cavity by diffusion (bulk flow) [43]. The diffusion capacity for proteins across the synovial membrane in rheumatoid arthritis depends on the degree of synovial inflammation and molecular size [43-45]. While both multimeric and trimeric subunit SP-D were present in serum, only trimeric forms could be demonstrated in synovial fluid. This further supports that diffusion is the major source of SP-D in the joint cavity although local degradation of the molecule cannot be excluded. Knowledge about the biologic properties of trimeric SP-D is incomplete. However, previous studies have indicated that trimers interact preferentially with specific microbes, microbial compounds or endogenous lipoproteins $[19,46]$ implying that trimeric SP-D may possess specialized functions as compared with multimeric SP-D. Previously, Gardai et al proposed a model for dual inflammatory activity of SP-D. In the absence of microbial ligands and cell debris, binding of SP-D to macrophages by the CRD region was suggested to be anti-inflammatory by blocking $\mathrm{p} 38$ mitogen-activated protein kinases ( $\mathrm{p} 38$ MAPK) [47]. By contrast, binding of microbial constituents to the CRD region of SP-D would lead to a proinflammatory response [47]. Recently, it was shown that posttranslational nitrosylation of cystein residues in the $\mathrm{N}$-terminus of SP-D (SNO-SP-D) caused by inflammation resulted in disruption of multimeric SP-D into nitrosylated trimers. This modified trimeric SP-D variant would subsequently initiate a pro-inflammatory response via calreticulin/CD91 receptor interaction and activate p38 MAPK [48]. Inflammatory signalling resulting in $\mathrm{p} 38$ phosphorylation has been identified as an important determinant of synovitis severity [49]. Thus, in theory the dominance of low molecular weight SP-D in synovial fluid observed in the present study may contribute to the maintenance of joint inflammation in RA.
SP-D in serum is suggested to originate primarily from pulmonary leakage [50]. It has previously been demonstrated that smoking increases SP-D in serum [22]. Our findings demonstrate that this also applies to RA patients implying that smoking is a confounder that should be corrected for in the statistical analysis. It has been hypothesized that anti-CCP antibodies can be triggered by smoking through citrullination of lung proteins in SE carriers [51]. We found no correlation between circulating SP-D and SE status in smoking and nonsmoking RA patients.

When interpreting the present results, the relatively large number of drop-outs should be considered. However, there was no difference with respect to baseline characteristics between completers and non-completers and the intention to treat analysis included a large majority of the cohort.

SP-D did not correlate to age in RA patients, but tended to be higher in males compared to females. By contrast, SP-D was significantly higher in control males as compared to females, and SP-D correlated positively with age. This disparity may be due to the different sizes of the RA and control populations and the relative overrepresentation of females in the RA cohort. Due to the difference in age distribution in the two populations and rather few controls aged above 50 years we used logistic regression with adjustment for gender and age instead of regular frequency matching in comparisons between controls and patients.

\section{Conclusions}

Circulating SP-D is subnormal at disease onset and after four years treatment in RA. There were no SP-D Met11Thr associations with RA disease activity or subnormal SP-D. While SP-D did not correlate with $\mathrm{x}$-ray progression, we found an inverse association between SP-D and disease activity markers suggesting that low systemic SP-D is involved in the initiation or maintenance of synovitis. Whereas both multimeric and trimeric SP-D variants occurred in serum, only low molecular forms were detected in synovial fluid where it may contribute to joint inflammation. Overall, this study suggests that SP-D is implicated in RA pathogenesis at the protein level.

\footnotetext{
Abbreviations

Anti-CCP: antibodies against cyclic citrullinated peptides; Cl: confidence interval; CIMESTRA: Ciclosporine, Methotrexate, Steroid in RA; CRP: c-reactive protein; DAS: disease activity score; DMARD: disease modifying antirheumatic drug; ES: erosion score; HAQ: health assessment questionnaire; HLA: human leukocyte antigen; IgM-RF: IgM-rheumatoid factor; JSN: Joint Space Narrowing score; MBL: mannan-binding lectin; MTX: methotrexate; RA: rheumatoid arthritis; SE: shared epitopes; SNP: single nucleotide polymorphism; SP-D: surfactant protein -D; TBS: TRIS-buffered saline; TSS: total Sharp-van der Heijde Score; VAS: visual analogue scale.
} 


\section{Acknowledgements}

We thank the study of metabolic syndrome and related components (GEMINAKAR) for providing serum and DNA control samples. In addition, we appreciate the expert laboratory assistance by Professor Peter Garred at Department of Clinical Immunology at Rigshospitalet, Copenhagen University Hospital, Denmark and Niels Heegaard, MD, DmSc at Department of Biochemistry and Immunology, Statens Serum Institut, Denmark, Professor C. Bendixen and A. Høj, MSc, PhD at the Department of Animal Breeding and Genetics, Danish Institute of Agricultural Sciences, Tjele, Denmark, for doing the SNP analyses.

This study was supported by The Danish Rheumatism Association, Region of Southern Denmark, Institute of Clinical Research at the University of Southern Denmark, The A.P. Møller Foundation for the Advancement of Medical Science, Guldsmed A.L. \& D. Rasmussens Mindefond and Else Poulsens Mindelegat.

\section{Author details}

${ }^{1}$ Department of Rheumatology, Odense University Hospital, Sdr. Boulevard 29, DK-5000 Odense C, Denmark and Institute of Clinical Research, University of Southern Denmark, Winsloewparken 19, DK-5000 Odense C, Denmark. ${ }^{2}$ Medical Biotechnology Centre, University of Southern Denmark, Winsloewparken 25, DK-5000 Odense C, Denmark. ${ }^{3}$ Department of Rheumatology, Rheumatism Hospital, Toldbodgade 3, DK-6300 Graasten, Denmark. ${ }^{4}$ Department of Rheumatology, Copenhagen University Hospitals, Hvidovre and Glostrup, Kettegaards Alle 30, DK-2650 Hvidovre, Denmark. ${ }^{5}$ Department of Rheumatology, Aarhus University Hospital, Noerrebrogade 44, DK-8000 Aarhus C, Denmark. 'Department of Rheumatology, Copenhagen University Hospital, Rigshospitalet, Blegdamsvej 9, DK-2100 Copenhagen, Denmark. ${ }^{7}$ Department of Rheumatology, Copenhagen University Hospitals, Herlev and Gentofte, Niels Andersens Vej 65, DK-2900 Hellerup, Denmark. ${ }^{8}$ Department of Radiology, Copenhagen University Hospital, Hvidovre, Kettegaards Alle 30, DK-2650 Hvidovre, Denmark. ${ }^{9}$ Department of Radiology, Aarhus University Hospital, Noerrebrogade 44, DK-8000 Aarhus C, Denmark.

\section{Authors' contributions}

All authors contributed to the design of the study, and the acquisition and interpretation of data. AFC performed the statistical analysis. AFC, PJ and GL drafted the manuscript. $\mathrm{KJ}$ carried out the immunoassays and gel filtration chromatography. AGJ and AV evaluated the $x$-ray data. All authors read and approved the final manuscript.

\section{Competing interests}

The authors declare that they have no competing interests.

Received: 26 August 2009 Revisions requested: 23 October 2009 Revised: 11 January 2010 Accepted: 8 March 2010 Published: 8 March 2010

\section{References}

1. Arend WP: The innate immune system in rheumatoid arthritis. Arthritis Rheum 2001, 44:2224-2234.

2. Garred P, Madsen HO, Marquart H, Hansen TM, Sørensen SF, Petersen J, Volck B, Svejgaard A, Graudal NA, Rudd PM, Dwek RA, Sim RB, Andersen V: Two edged role of mannose binding lectin in rheumatoid arthritis: a cross sectional study. J Rheumatol 2000, 27:26-34.

3. Saevarsdottir S, Vikingsdottir T, Vikingsson A, Manfredsdottir V, Geirsson AJ, Valdimarsson H: Low Mannose Binding Lectin Predicts Poor Prognosis in Patients with Early Rheumatoid Arthritis. A Prospective Study. J Rheumatol 2001, 28:728-734.

4. Graudal NA, Madsen HO, Tarp U, Svejgaard A, Jurik AG, Graudal HK, Garred P: The association of variant mannose-binding lectin genotypes with radiographic outcome in rheumatoid arthritis. Arthritis Rheum 2000, 43:515-521.

5. Jacobsen $S$, Madsen $H O$, Klarlund $M$, Jensen $T$, Skjodt $H$, Jensen $K E$, Svejgaard A, Garred P, TIRA Group: The influence of mannose binding lectin polymorpisms on disease outcome in early polyarthritis. J Rheumatol 2001, 28:935-942.

6. Hoegh SV, Lindegaard HM, Sorensen GL, Hoj A, Bendixen C, Junker P, Holmskov U: Circulating Surfactant Protein D is Decreased in Early
Rheumatoid Arthritis: A 1-year Prospective Study. Scand J Immunol 2008, 67:71-76.

7. Holmskov U: Collectins and collectin receptors in innate immunity. APMIS Suppl 2000, 100:1-59.

8. Holmskov U, Thiel S, Jensenius JC: Collectins and ficolins: Humoral Lectins of the Innate Immune Defense. Annu Rev Immunol 2003, 21:547-578.

9. Crouch E, Chang D, Rust K, Persson A, Heuser J: Recombinant pulmonary surfactant protein D. Post-translational modification and molecular assembly. J Biol Chem 1994, 269:15808-15813.

10. Bufler P, Schmidt B, Schikor D, Bauernfeind A, Crouch EC, Griese M: Surfactant Protein A and D Differently Regulate the Immune Response to Nonmucoid Pseudomonas aeruginosa and Its Lipopolysaccharide. Am J Respir Cell Mol Biol 2003, 28:249-256.

11. Hartshorn KL, White MR, Tecle T, Tornoe I, Sorensen GL, Crouch EC, Holmskov $U$ : Reduced influenza viral neutralizing activity of natural human trimers of surfactant protein D. Respir Res 2007, 8:9.

12. Hartshorn KL, Crouch E, White MR, Colamussi ML, Kakkanatt A, Tauber B, Shepherd V, Sastry KN: Pulmonary surfactant proteins A and D enhance neutrophil uptake of bacteria. Am J Physiol 1998, 274:L958-L969.

13. Leth-Larsen R, Garred P, Jensenius H, Meschi J, Hartshorn K, Madsen J, Tornoe I, Madsen HO, Sorensen G, Crouch E, Holmskov U: A common polymorphism in the SFTPD gene influences assembly, function, and concentration of surfactant protein D. J Immunol 2005, 174:1532-1538.

14. Crouch E, Parghi D, Kuan SF, Persson A: Surfactant protein D: subcellular localization in nonciliated bronchiolar epithelial cells. Am J Physiol 1992, 263:L60-L66

15. Stahlman MT, Gray ME, Hull WM, Whitsett JA: Immunolocalization of surfactant Protein-D (SP-D) in human fetal, newborn, and adult tissues. J Histochem Cytochem 2002, 50:651-660.

16. Madsen J, Kliem A, Tornoe I, Skjodt K, Koch C, Holmskov U: Localization of lung surfactant protein $\mathrm{D}$ on mucosal surfaces in human tissues. J Immunol 2000, 164:5866-5870

17. Honda Y, Kuroki Y, Matsuura E, Nagae H, Takahashi H, Akino T, Abe S: Pulmonary surfactant protein $\mathrm{D}$ in sera and bronchoalveolar lavage fluids. Am J Respir Crit Care Med 1995, 152:1860-1866.

18. Kankavi O: Increased expression of surfactant protein $A$ and $D$ in rheumatoid arthritic synovial fluid. Croat Med J 2006, 47:155-161.

19. Leth-Larsen R, Nordenbaek C, Tornoe I, Moeller V, Schlosser A, Koch C, Teisner B, Junker P, Holmskov U: Surfactant protein D (SP-D) serum levels in patients with community-acquired pneumonia. Clin Immunol 2003, 108:29-37.

20. Nagae H, Takahashi H, Kuroki Y, Honda Y, Nagata A, Ogasawara Y, Abe S, Akino T: Enzyme-linked immunosorbent assay using $F\left(a b^{\prime}\right) 2$ fragment for the detection of human pulmonary surfactant protein $D$ in sera. Clin Chim Acta 1997, 266:157-171.

21. Ni M, Evans DJ, Hawgood S, Anders EM, Sack RA, Fleiszig SMJ: Surfactant protein $D$ is present in human tear fluid and the cornea and inhibits epithelial cell invasion by pseudomonas aeruginosa. Infect Immun 2005, 73:2147-2156.

22. Sorensen GL, Hjelmborg J, Kyvik KO, Fenger M, Hoj A, Bendixen C, Sorensen T, Holmskov U: Genetic and environmental influences of surfactant protein D serum levels. Am J Physiol Lung Cell Mol Physiol 2006, 290:L1010-L1017.

23. Hetland ML, Stengaard-Pedersen $\mathrm{K}$, Junker $\mathrm{P}$, Lottenburger $\mathrm{T}$, Ellingsen $\mathrm{T}$, Andersen LS, Hansen I, Skjødt H, Pedersen JK, Lauridsen UB, Svendsen A, Tarp U, Pødenphant J, Hansen G, Lindegaard H, de Carvalho A, Østergaard M, Hørslev-Petersen K, the Cimestra Study Group: Combination treatment with methotrexate, ciclosporine, and intraarticular betamethasone compared with methotrexate and intraarticular betamethasone in early active rheumatoid arthritis. Arthritis Rheum 2006, 54:1401-1409.

24. Hetland ML, Stengaard-Pedersen K, Junker P, Lottenburger T, Hansen I, Andersen LS, Tarp U, Svendsen A, Pedersen JK, Skjodt H, Lauridsen UB, Ellingsen $T$, Hansen $G$, Lindegaard $H$, Vestergaard A, Jurik AG, Ostergaard $M$, Horslev-Petersen K: Aggressive combination therapy with intraarticular glucocorticoid injections and conventional DMARDs in early rheumatoid arthritis Two Year Clinical and Radiographic Results From The CIMESTRA Study. Ann Rheum Dis 2008, 67:815-822.

25. Arnett FC, Edworthy SM, Bloch DA, MCShane DJ, Fries JF, Cooper NS, Healey LA, Kaplan SR, Liang MH, Luthra HS, et al: The American 
Rheumatism Association 1987 revised criteria for the classification of rheumatoid arthritis. Arthritis Rheum 1988, 31:315-324.

26. Thorsen H, Hansen TM, Mckenna SP, Sørensen SF, Whalley D: Adaption into Danish of the stanford health assessment questionnaire (HAQ) and the rheumatoid arthritis quality of life scale (RaQol). Scand J Rheumatol 2001, 30:103-109.

27. Prevoo MLL, van T Hof MA, Kuper HH, van Leeuwen MA, Putte van de LBA, van Riel PL: Modified disease activity scores that include twenty-eightjoint counts. Arthritis Rheum 1995, 38:44-48.

28. Høier-Madsen M, Nielsen LP, Møller S: Determination of IgM rheumatoid factors by enzyme-linked immunosorbent assay (ELISA). Ugeskr Laeger 1986, 148:2018-2021.

29. Nishimura K, Sugiyama D, Kogata Y, Tsuji G, Nakazawa T, Kawano S, Saigo K, Morinobu A, Koshiba M, Kuntz KM, Kamae I, Kumagai S: Meta-analysis: Diagnostic Accuracy of Anti-Cyclic Citrullinated Peptide Antibody and Rheumatoid Factor for Rheumatoid Arthritis. Ann Intern Med 2007, 146:797-808.

30. Vasiliauskiene L, Wiik A, Hoier-Madsen M: Prevalence and clinical significance of antikeratin antibodies and other serological markers in Lithuanian patients with rheumatoid arthritis. Ann Rheum Dis 2001, 60:459-466.

31. Heijde van der D: How to read radiographs according to Sharp/van der Heijde method. J Rheumatol 2000, 27:261-263.

32. Bathon JM, Martin RW, Fleischmann RM, Tesser JR, Schiff MH, Keystone EC, Genovese MC, Wasko M, Moreland LW, Weaver AL, Markenson J, Finck BK: A Comparison of Etanercept and Methotrexate in Patients with Early Rheumatoid Arthritis. N Engl J Med 2000, 343:1586-1593.

33. Hetland $M$, Ejbjerg $B$, Horslev-Petersen $K$, Jacobsen $S$, Vestergaard $A$, Jurik $A$, Stengaard-Pedersen $\mathrm{K}$, Junker $\mathrm{P}$, Lottenburger $\mathrm{T}$, Hansen I, Andersen LS, Tarp U, Skjodt H, Pedersen J, Majgaard O, Svendsen AJ, Ellingsen T, Lindegaard HM, Christensen AF, Vallo J, Torfing T, Narvestad E, Thomsen HS, Ostergaard M, CIMESTRA study group: MRI bone oedema is the strongest predictor of subsequent radiographic progression in early rheumatoid arthritis. Results from a 2 year randomized controlled trial (CIMESTRA). Ann Rheum Dis 2009, 68:384-390.

34. Kimura A, Sasazuki T: Eleventh International Histocompatibility workshop. HLA 1991 Oxford: Oxford University PressTsuji K, Aizawa M, Sasazuki M 1992.

35. Heidinger K, Konig IR, Bohnert A, Kleinsteiber A, Hilgendorff A, Gortner L, Ziegler A, Chakraborty T, Bein G: Polymorphisms in the human surfactant protein-D (SFTPD) gene: strong evidence that serum levels of surfactant protein-D (SP-D) are genetically influenced. Immunogenetics 2005, 57:1-7.

36. Palaniyar N, Clark H, Nadesalingam J, Hawgood S, Reid KB: Surfactant protein $\mathrm{d}$ binds genomic DNA and apoptotic cells, and enhances their clearance, in vivo. Ann NY Acad Sci 2003, 1010:471-475.

37. Palaniyar N, Nadesalingam J, Clark H, Shih MJ, Dodds AW, Reid KB: Nucleic acid is a novel ligand for innate, immune pattern recognition collectins surfactant proteins $A$ and $D$ and mannose-binding lectin. $J$ Biol Chem 2004, 279:N32728-32736.

38. Liu G, Wu C, Wu Y, Zhao Y: Phagocytosis of apoptotic cells and immune regulation. Scand I Immunol 2006, 64:1-9.

39. Palaniyar N, Clark H, Nadesalingam J, Shih MJ, Hawgood S, Reid KB: Innate immune collectin surfactant protein $D$ enhances the clearance of DNA by macrophages and minimizes anti-DNA antibody generation. $J$ Immunol 2005, 174:17352-7358.

40. Vandivier RW, Ogden CA, Fadok VA, Hoffmann PR, Brown KK, Botto M, Walport MJ, Fisher JH, Henson PM, Greene KE: Role of Surfactant Proteins A, D, and C1q in the Clearance of Apoptotic Cells In Vivo and In Vitro: Calreticulin and CD91 as a Common Collectin Receptor Complex. J Immunol 2002, 169:3978-3986.

41. Brown AK, Quinn MA, Karim Z, Conaghan PG, Peterfy CG, Hensor E, Wakefield RJ, O'Connor PJ, Emery P: Presence of significant synovitis in rheumatoid arthritis patients with disease-modifying antirheumatic drug-induced clinical remission. Arthritis Rheum 2006, 54:3761-3773.

42. Brown AK, Conaghan PG, Karim Z, Quinn MA, Ikeda K, Peterfy CG, Hensor E, Wakefield RJ, O'Connor PJ, Emery P: An explanation for the apparent dissociation between clinical examination and continued structural detoriation in rheumatoid arthritis. Arthritis Rheum 2008, 58:2958-2967.

43. Kushner I, Somerville JA: Permeability of human synovial membrane to plasma proteins. Relationship to molecular size and inflammation. Arthritis Rheum 1971, 14:560-570.
44. Pejovic M, Stankovic A, Mitrovic DR: Determination of the apparent synovial permeability in the knee joint of patients suffering from osteoarthritis and rheumatoid arthritis. Br J Rheumatol 1995, 34:520-524.

45. Simkin PA, Pizzorno JE: Synovial permeability in rheumatoid arthritis. Arthritis Rheum 1979, 22:689-696.

46. Sorensen GL, Hoegh SV, Leth-Larsen R, Thomsen TH, Floridon C, Smith K, Kejling K, Tornoe I, Crouch EC, Holmskov U: Multimeric and trimeric subunit SP-D are inconvertible structures with distinct ligand interaction. Mol Immunol 2009, 10.1016/..molimm.2009.06.005.

47. Gardai SJ, Xiao YQ, Dickinson M, Nick JA, Voelker DR, Greene KE, Henson PM: By binding SIRP[alpha] or Calreticulin/CD91, lung collectins act as dual function surveillance molecules to suppress or enhance inflammation. Cell 2003, 115:13-23.

48. Guo CJ, Atochina-Vasserman EN, Abramova E, Foley JP, Zaman A, Crouch E, Beers MF, Savani RC, Gow AJ: S-nitrosylation of surfactant protein-D controls inflammatory function. PLOS Biol 2008, 6:e266.

49. Schett G, Zwerina J, Firestein GS: The p38 mitogen-activated protein kinase (MAPK) pathway in rheumatoid arthritis. Ann Rheum Dis 2008, 67:909-916.

50. Hermans CEDR, Bernard ALFR: Lung epithelium-specific proteins. characteristics and potential applications as markers. Am J Respir Crit Care Med 1999, 159:646-678.

51. Klareskog L, Stolt P, Lundberg K, Källberg H, Bengtsson C, Grunewald J, Rönnelid J, Harris HE, Ulfgren AK, Rantapää-Dahlqvist S, Eklund A, Padyukov $L$, Alfredsson $L$, the ElRA study group: A new model for an etiology of rheumatoid arthritis: Smoking may trigger HLA-DR (shared epitope)-restricted immune reactions to autoantigens modified by citrullination. Arthritis Rheum 2006, 54:38-46.

doi:10.1186/ar2948

Cite this article as: Christensen et al:: Circulating surfactant protein -D is low and correlates negatively with systemic inflammation in early, untreated rheumatoid arthritis. Arthritis Research \& Therapy 2010 12:R39.

\section{Submit your next manuscript to BioMed Central and take full advantage of:}

- Convenient online submission

- Thorough peer review

- No space constraints or color figure charges

- Immediate publication on acceptance

- Inclusion in PubMed, CAS, Scopus and Google Scholar

- Research which is freely available for redistribution

Submit your manuscript at www.biomedcentral.com/submit
C Biomed Central 